\title{
Incidence of the Parasitism of Chicken Mite Dermanyssus gallinae Parasitizing and Propagating on Chicken Even in the Daytime and Their Life Cycle
}

\author{
Hitoshi Nakamae ${ }^{1}$, Shigeyuki Kishi ${ }^{2}$, Kozo Fujisaki ${ }^{3}$, \\ Seiichi Oshiro ${ }^{4}$ and Kenji Furuta ${ }^{4}$ \\ ${ }^{1}$ United Graduate School of Agricultural Sciences, Kagoshima University. \\ Korimoto, Kagoshima 890 \\ ${ }^{2}$ Nishimikawa Livestock Hygiene Service Center. Miai, Okazaki, Aichi 400 \\ ${ }^{3}$ Japan International Research Center for Agricultural Sciences. Owashi, \\ Tsukuba, Ibaraki 305 \\ ${ }^{4}$ College of Agriculture, University of the Ryukyus, Senbaru, \\ Nishihara, Okinawa 903-01
}

The incidence of the parasitism of chicken mites Dermanyssus gallinae parasitizing and propagating on chickens day and night was observed in a chicken farm. The incidence of the parasitism was induced by the artificial inoculation of protonymphs hatched from eggs of chicken mites parasitizing in the daytime on chickens. Furthermore, their life cycle was clarified.

1. It was observed in a chicken farm that the parasitism of northern fowl mites occurred on chickens, subsequently northern fowl mites and chicken mites were found on the same chickens and finally the chickens were parasitized with chicken mites alone. Chicken mites parasitized and propagated on the chickens day and night without leaving the chickens before daybreak.

2. The parasitism of chicken mites on chickens even in the daytime was established irrespective of the presence or absence of parasitic northern fowl mites when the protonymphs of chicken mites parasitizing in the daytime were inoculated artificially on chickens. The number of chicken mites parasitized on the chickens increased when the chickens were parasitized preliminarily with northern fowl mites.

3. The life cycle of the chicken mites parasitizing and propagating on the chickens day and night was the same as that of common chicken mites which sucked blood from chickens at night and left them before daybreak.

(Jpn. Poult. Sci., 34 : 240-247, 1997)

Keywords : parasitism, chicken mite, northern fowl mite, chicken mite parasitizing and propagating day and night, life cycle

It is considered that chicken mites Dermanyssus gallinae suck blood from chickens at night and leave the chickens before daybreak. They stay in cracks, crevices and droppings in the chicken house in the daytime (BAKER et al., 1956 ; HARRISON, 1963; KIRKWOOD, 1963 : ARENDS, 1991). However, the authors have reported the presence of chicken mite sparasitizing on chickens even in the daytime without leaving them before daybreak. They parasitize and propagate on chickens day and night. The authors happen to find the existence of these mites in several chicken farms at Aichi Prefecture (NAKAMAE et al., $1996 \mathrm{a}, 1996 \mathrm{~b}$ ).

This paper deals with three subjects : the incidence of the parasitism of chicken

Received October 23, 1996 Accepted December 5, 1996 
mites parasitizing in the daytime in a chicken farm, the incidence of the parasitism induced by the artificial inoculation of their protonymphs on chickens, and their life cycle.

\section{Materials and Methods}

The incidence of parasitism of chicken mites parasitizing on chickens in the daytime without leaving before daybreak was observed in a chicken farm where the parasitism had occurred (Expt. 1), and the parasitism was confirmed by artificial inoculation of protonymphs of the chicken mites on the chickens (Expt. 2). Lastly, the life cycle of the chicken mites was investigated (Expt. 3). The number of parasitic mites was recorded by using the DeVANEY's mite index (1979) as shown in footnotes of the Table 1, and the morphological characteristics of the mites were observed under an optical microscope or magnifying glass to identify the species of them.

Experiment 1: The experiment was carried out at a chicken farm at Takahama, Aichi prefecture. The incidence of the parasitism of chicken mites parasitizing in the daytime was recognized at the farm. Forty White Leghorns of 220 days of age which had been confirmed to be free from the ectoparasites were housed into the central part of the cage laying house described previously (NAKAmaE et al., $1996 \mathrm{a}, 1996 \mathrm{~b}$ ). Around the cage keeping the chickens used in the examination, chickens of the same age which were not to be used for examination were kept in cages. The number of these unexamining chickens had already been parasitized with both northern fowl mites and chicken mites by April 7 when the examining chickens were housed. Then, the examining chickens were exposed to an opportunity of being parasitized with these mites. The observation of the parasitism of the mites was carried out once every week through 210 days after the housing of the examining chickens. When chicken mites were observed on the chickens in the day time from 10 a.m. to 3 p.m., the chicken mites were observed again at night from 8 p.m. to 12 p.m. to confirm the parasitism. The mite index of each chicken examined was recorded individually.

Experiment $2:$ Female chicken mites parasitizing in the daytime and common chicken mites not parasitizing in the daytime were collected using Pasteur pipettes. The pipettes containing mites were placed within desiccators kept at $30^{\circ} \mathrm{C}$. The chicken mites collected were kept for 4 days and the protonymphs hatched from the eggs were sampled.

On the other hand, 54 laying chickens of 245 days of age free from ectoparasites were divided into 3 flocks. Chickens were kept in individual cages. These cages were isolated from each other so that the inoculated mites could not migrate to any other cage.

Chickens in Flock 1 were preliminarily parasitized with northern fowl mites. Individual mite index of the northern fowl mites was 4 at the start of the experiment (on May 12). The protonymphs of chicken mites parasitizing in the daytime were released to the cage floors of the Flock 1 . The number of the released protonymphs was 250 per cage floor. In the same way, the protonymphs of chicken mites parasitizing in the daytime and the protonymphs of common chicken mites not parasiting in 
the daytime were also made to parasitize on the chickens of the Flocks 2 and 3, respectively. The experiment was made through 56 days after the releasing the protonymphs and the observation of the parasitism was carried out in day and night in the same way as Expt. 1.

Experiment 3 : Eggs of the chicken mites parasitizing in the daytime were collected into Pasteur pipettes from chickens which had been parasitized with chicken mites in the daytime. In the same way, eggs of the common chicken mites parasitizing only at night were collected. Both ends of each pipette were sealed with cotton plugs. The pipettes were held horizontally in desiccators with saturated saline. The desiccators were placed at the room temperature. The temperature and the relative humidity in the desiccators ranged from 20 to $29^{\circ} \mathrm{C}$ and from 62 to $82 \%$, respectively. For the investigation of the life cycle of chicken mite, 40 eggs of each chicken mites was used.

The morphological characteristics of each developing stage of the chicken mite were observed at an interval of 12 hours. When the developing stage accomplished in a short time, the observation interval was shortened from 2 to 6 hours as described by WOOD (1917).

\section{Results}

Incidence of the parasitism of chicken mites parasiting in the daytime in a chicken farm (Expt. 1)

The incidence of parasitism of northern fowl mites and chicken mites in a chicken farm is presented in Table 1. In 7 days after the housing (on April 14), the parasitism of northern fowl mites was observed on $24(60 \%)$ chickens. The degree of parasitism was slight as the mean mite index was 1.8. The parasitism of northern fowl mites occurred on all the chickens and the mean mite index was 3.7 in 14 days after the housing. The mean mite index increased to 4.0 in 28 days after the housing. The parasitism of the 2 species of mite, northern fowl mites and chicken mites, was observed on $15(37.5 \%)$ chickens in 35 days after the housing. The mean mite index of the 15 chickens with the parasitism of the 2 species of mite was 4.2 and the mean value of remaining 25 chickens with the parasitism of northern fowl mites was 4.1 . In 56 days after the housing, all the chickens were parasitized with the 2 species of mite. The parasitism with 2 species of mite was observed till the 133rd days after the housing.

In 63 days after the housing, the parasitism of chicken mite alone was observed on 4 chickens. In 140 days after the housing, all the chickens were parasitized with chicken mites alone. No northern fowl mites were observed on the chickens.

The formation of a mite cluster discribed previously by NAKAMAE et al. (1996 b) was observed on the abdominal tract of the chickens parasitized with chicken mites. The mites parasitized on them as indicated by a mite index of 5 . In 210 days after the housing (on November 3), the parasitism of the chicken mites parasitizing in the daytime was observed in all the chickens. The mean mite index decreased to 2.4. 
Table 1. Incidence of the parasitism of chicken mites parasitizing in the daytime in a chicken farm (Expt. 1)

\begin{tabular}{|c|c|c|c|c|c|c|}
\hline \multirow{2}{*}{$\begin{array}{c}\text { Days } \\
\text { after } \\
\text { housing }\end{array}$} & \multicolumn{2}{|c|}{$\begin{array}{l}\text { Parasitized with } \\
\text { NFM }^{1)}\end{array}$} & \multicolumn{2}{|c|}{$\begin{array}{l}\text { Parasitized with } \\
\text { NFM and } \mathrm{CM}^{2}\end{array}$} & \multicolumn{2}{|c|}{$\begin{array}{c}\text { Parasitized with } \\
\text { CM }\end{array}$} \\
\hline & $\begin{array}{l}\text { No. of } \\
\text { chickens }\end{array}$ & $\begin{array}{l}\text { Mite } \\
\text { index }\end{array}$ & $\begin{array}{l}\text { No. of } \\
\text { chickens }\end{array}$ & $\begin{array}{l}\text { Mite } \\
\text { index }\end{array}$ & $\begin{array}{l}\text { No. of } \\
\text { chickens }\end{array}$ & $\begin{array}{l}\text { Mite } \\
\text { index }\end{array}$ \\
\hline 7 & 24 & $1.8 \pm 0.4^{3)}$ & 0 & & 0 & \\
\hline 14 & 40 & $2.8 \pm 0.4$ & 0 & & 0 & \\
\hline 21 & 40 & $3.7 \pm 0.5$ & 0 & & 0 & \\
\hline 28 & 40 & $4.0 \pm 0.5$ & 0 & & 0 & \\
\hline 35 & 25 & $4.1 \pm 0.4$ & 15 & $4.2 \pm 0.4$ & 0 & \\
\hline 42 & 13 & $4.2 \pm 0.6$ & 27 & $4.2 \pm 0.5$ & 0 & \\
\hline 49 & 1 & 4.0 & 39 & $4.2 \pm 0.4$ & 0 & \\
\hline 56 & 0 & & 40 & $4.5 \pm 0.5$ & 0 & \\
\hline 63 & 0 & & 36 & $4.6 \pm 0.5$ & 4 & $4.5 \pm 0.5$ \\
\hline 70 & 0 & & 29 & $4.6 \pm 0.5$ & 11 & $4.6 \pm 0.5$ \\
\hline 77 & 0 & & 28 & $4.6 \pm 0.5$ & 12 & $4.6 \pm 0.5$ \\
\hline 84 & 0 & & 26 & $4.5 \pm 0.6$ & 14 & $4.6 \pm 0.5$ \\
\hline 91 & 0 & & 27 & $4.9 \pm 0.6$ & 13 & $4.9 \pm 0.5$ \\
\hline 98 & 0 & & 17 & $4.4 \pm 0.5$ & 23 & $4.2 \pm 0.5$ \\
\hline 105 & 0 & & 13 & $4.4 \pm 0.5$ & 27 & $4.0 \pm 0.7$ \\
\hline 112 & 0 & & 10 & $4.2 \pm 0.4$ & 30 & $3.8 \pm 0.8$ \\
\hline 119 & 0 & & 6 & $3.8 \pm 0.4$ & 34 & $3.7 \pm 0.8$ \\
\hline 126 & 0 & & 3 & $3.7 \pm 0.5$ & 37 & $3.5 \pm 1.0$ \\
\hline 133 & 0 & & 1 & 4.0 & 39 & $3.4 \pm 0.9$ \\
\hline 140 & 0 & & 0 & & 40 & $3.3 \pm 0.8$ \\
\hline 210 & 0 & & 0 & & 40 & $2.4 \pm 0.6$ \\
\hline
\end{tabular}

No. of chickens examined : 40

1) NFM : Northern fowl mite, ${ }^{2)} \mathrm{CM}$ : Chicken mite

3) DeVAnEY's mite index (1979), Mean $\pm \mathrm{SD}$

Index $1: 1$ to 10

$2: 11$ to 100

$3: 101$ to 1,000

of mites parasitized per chicken

$4: 1,001$ to 10,000

5 : more than 10,001

\section{Incidence of the parasitism of chicken mites parasiting in the daytime induced} by experimental procedure (Expt. 2)

The protonymphs obtained by hatching eggs of chicken mites parasitizing in the daytime were inoculated on chickens preliminarily parasitized with northern fowl mites and chickens were kept free from ectoparasites. The results of the observation of the parasitic state after the inoculation are presented in Table 2. Adult chicken mites were observed on the chickens preliminarily parasitized with northern fowl mites (Flock 1) in 5 days after releasing the protonymphs onto the chicken mites. The adult chicken mites and northern fowl mites were detectable from the chicken day and night. The parasitism of the 2 species of mites, northern fowl mites and chicken mites, was obseved from 5 th to 35 th days after releasing the protonymphs. The mite index 
Table 2. Incidence of the parasitism of the chicken mites parasitizing in the daytime induced by artificial inoculation (Expt. 2)

\begin{tabular}{|c|c|c|c|c|c|c|c|c|c|}
\hline \multirow{4}{*}{$\begin{array}{l}\text { Days } \\
\text { after } \\
\text { releasing } \\
\text { proto- } \\
\text { nymphs }\end{array}$} & \multicolumn{8}{|c|}{$\begin{array}{c}\text { Protonymphs of chicken mites parasitizing } \\
\text { in the daytime inoculated on }\end{array}$} & \multirow{3}{*}{$\begin{array}{l}\text { Protony mphs of } \\
\text { common chicken } \\
\text { mite inoculated } \\
\text { on chickens with } \\
\text { no parasitism } \\
\text { (Flock 3) } \\
\begin{array}{l}\text { Parasitized with } \\
\text { common } \mathrm{CM}^{3)}\end{array}\end{array}$} \\
\hline & \multicolumn{6}{|c|}{$\begin{array}{l}\text { Chickens preliminarily parasitized with } \\
\text { northern fowl mites (Flock 1) }\end{array}$} & \multirow{2}{*}{\multicolumn{2}{|c|}{$\begin{array}{c}\begin{array}{c}\text { Chickens with } \\
\text { no parasitism } \\
\text { (Flock 2) }\end{array} \\
\begin{array}{c}\text { Parasitized } \\
\text { with CM }\end{array}\end{array}$}} & \\
\hline & \multicolumn{2}{|c|}{$\begin{array}{l}\text { Parasitized } \\
\text { with } \text { NFM }^{1)}\end{array}$} & \multicolumn{2}{|c|}{$\begin{array}{l}\text { Parasitized with } \\
\text { NFM and } \mathrm{CM}^{2)}\end{array}$} & \multicolumn{2}{|c|}{$\begin{array}{l}\text { Parasitized } \\
\text { with CM }\end{array}$} & & & \\
\hline & $\begin{array}{l}\text { No. of } \\
\text { chickens }\end{array}$ & $\begin{array}{l}\text { Mite } \\
\text { index } \mathrm{cl}\end{array}$ & $\begin{array}{l}\text { No. of } \\
\text { chickens }\end{array}$ & $\begin{array}{l}\text { Mite } \\
\text { index }\end{array}$ & $\begin{array}{l}\text { No. of } \\
\text { chickens }\end{array}$ & $\begin{array}{l}\text { Mite } \\
\text { index }\end{array}$ & $\begin{array}{l}\text { No. of } \\
\text { chickens }\end{array}$ & $\begin{array}{l}\text { Mite } \\
\text { index }\end{array}$ & $\begin{array}{c}\text { No. of } \text { Mite } \\
\text { chickens index }\end{array}$ \\
\hline 1 & 18 & $4.0 \pm 0.0^{4)}$ & 0 & & 0 & & 0 & & 0 \\
\hline 2 & 18 & $4.0 \pm 0.0$ & 0 & & 0 & & 0 & & 0 \\
\hline 3 & 18 & $4.0 \pm 0.0$ & 0 & & 0 & & 14 & $1.0 \pm 0.0$ & 0 \\
\hline 4 & 18 & $4.0 \pm 0.0$ & 0 & & 0 & & 18 & $1.2 \pm 0.1$ & 0 \\
\hline 5 & 2 & $4.0 \pm 0.0$ & 16 & $4.0 \pm 0.0$ & 0 & & 18 & $2.1 \pm 0.5$ & 0 \\
\hline 6 & 0 & & 18 & $4.0 \pm 0.0$ & 0 & & 18 & $2.4 \pm 0.5$ & 0 \\
\hline 7 & 0 & & 18 & $4.0 \pm 0.0$ & 0 & & 18 & $2.3 \pm 0.5$ & 0 \\
\hline 14 & 0 & & 18 & $4.0 \pm 0.0$ & 0 & & 18 & $2.4 \pm 0.5$ & 0 \\
\hline 21 & 0 & & 17 & $4.0 \pm 0.0$ & 1 & $4.0 \pm 0.0$ & 18 & $2.4 \pm 0.5$ & 0 \\
\hline 28 & 0 & & 10 & $4.0 \pm 0.0$ & 8 & $4.0 \pm 0.0$ & 18 & $2.3 \pm 0.5$ & 0 \\
\hline 35 & 0 & & 4 & $4.0 \pm 0.0$ & 14 & $4.0 \pm 0.0$ & 18 & $2.4 \pm 0.5$ & 0 \\
\hline 42 & 0 & & 0 & & 18 & $4.0 \pm 0.0$ & 18 & $2.4 \pm 0.5$ & 0 \\
\hline 49 & 0 & & 0 & & 18 & $4.1 \pm 0.2$ & 18 & $2.5 \pm 0.5$ & 0 \\
\hline 56 & 0 & & 0 & & 18 & $4.1 \pm 0.2$ & 18 & $2.4 \pm 0.5$ & 0 \\
\hline
\end{tabular}

1) NFM : Northern fowl mite. ${ }^{2)} \mathrm{CM}$ : Chicken mite.

${ }^{3)}$ Common chicken mites were not found on chickens in the daytime. They left chickens before daybreak.

4) DEVAnEy's mite index (1979), Mean $\pm \mathrm{SD}$, Chickens were examined 18 in each flock.

of all the chickens was 4 . The parasitism of chicken mites alone without northern fowl mites was recognized in 21 days after releasing the protonymphs. In 42 days after the releasing, all the chickens were parasitized with chicken mites alone. The mean mite index was 4.0 or more, but no clusters (NAKAMAE et al., 1996 b) of chicken mites were observed.

The protonymphs of chicken mites parasitizing in the daytime were released to the cage floors where the chickens free from ectoparasites were kept (Flock 2). In 3 days after the releasing protonymphs, the parasitism of chicken mites were recognized on them. Thereafter, chicken mites were found on them day and night, while the mean mite index did not increase to 2.5. A small number of the chicken mites (less than 100 per chicken) parasitized on the chickens.

On the other hand, the protonymphs of common chicken mites with no habit of parasitizing on chickens in the daytime were inoculated on the chickens free from ectoparasites(Flock 3). No chicken mites were observed on all the chickens in the daytime, while they were observed at night. The common chicken mites parasitized on chickens only at night and they left the chickens before daybreak. 
Table 3. Comparison of the life cycle of chicken mite parasitizing in the daytime with common chicken mite leaving chickens before daybreak (Expt. 3)

\begin{tabular}{lcc}
\hline \multicolumn{1}{c}{$\begin{array}{c}\text { Developing stage of } \\
\text { chicken mite }\end{array}$} & $\begin{array}{c}\text { Chicken mites parasitizing } \\
\text { day in the daytime }\end{array}$ & $\begin{array}{c}\text { Chicken mites parasitizing } \\
\text { at night only }\end{array}$ \\
\hline From egg laid to hatch (day) & $1-2$ & $1-1.5$ \\
Hatchability (\%) & 96.7 & 96.0 \\
Period of larva (day) & 1 & 1 \\
Period of protonymph (day) & 1 & 1 \\
Period of deutonymph (day) & 2 & $1-2$ \\
Days from hatch to adult & $8-9$ & $8-9$ \\
Days from adult to egg laying & $1-3$ & $1-3$ \\
Egg laying period (day) & $1-4$ & $1-4$ \\
No. of eggs laid per adult & $4.1 \pm 1.9$ & $4.0 \pm 1.7$ \\
\hline
\end{tabular}

The number of eggs used in each treatment was 50 .

${ }^{1)}$ Mean $\pm S D$

\section{Life cycle of chicken mite parasitizing in the daytime (Expt. 3)}

The life cycle of chicken mite parasitizing in the daytime and that of common chicken mite are presented in Table 3. No difference was recognized in life cycle between the chicken mite parasitizing in the daytime and the common chicken mites.

\section{Discussion}

The authors have reported that the incidence of the parasitism of chicken mites in the daytime might be required for the parasitism of northern fowl mites (NAKAMAE et $a l ., 1996 \mathrm{~b})$. From the results of this study on the incidence of the parasitism of chicken mites in the daytime in the chicken farm (Table 1), it was observed that the parasitism of northern fowl mites occurred, subsequently chicken mites parasitized on the chickens and finally the chickens were parasitized with the chicken mites alone. Futhermore, the same process of establishment of the parasitism of the chicken mites parasitizing in the daytime was observed when the protonymphs of the chicken mites were inoculated on chickens preliminarily parasitized with northern fowl mites (Flock 1 in Table 2). These facts support the assumption in a previous report (NAKAMAE et al., 1996 b). However, the results of the Flock 2 of the Expt. 2 indicated that the parasitism of chicken mites parasitizing in the daytime was established on the chickens without the presence of the parasitism of northern fowl mites (Flock 2 in Table 2). This fact denied the assumption discribed in the previous report (NAKAMAE et al., $1996 \mathrm{~b}$ ).

Mite index was less than 3 when the chickens had not preliminarily parasitized with northern fowl mites as indicating the result of Flock 2 in the Table 2. The number of chicken mites parasitized was less than 100 per chicken. For this reason, it is considered that the existence of chicken mites parasitizing and propagating on chickens day and night was failed to notice in the previous studies. Both cases of chicken farm and artificial inoculation, the mite index of the chickens preliminarily parasitized with northern fowl mites increased to 4.0 or more (Tables 1 and 2). When northern fowl mites parasitized on chickens preliminarily, the number of chicken mites 
parasitizing on chickens increased.

When the protonymphs of the chicken mites parasitizing in the daytime were inoculated on the chickens, adult chicken mites developed from the protonymphs were detectable from the chickens at the daytime. It is considered that characteristics of the chicken mite parasitizing in the daytime were transmissible to their next generation. This should further be examined in detail.

It was in 35 days after the housing that the chicken mites were detected on the chicken examined in the chicken farm (Table 1). Adult chicken mites, however, were detectable in 5 days after the inoculation of the protonymphs of chicken mites (Flock 1 in Table 2). Differences were also shown in the period of the parasitism of northern fowl mites with chicken mite between observing results in chicken farm (from 36 to 133 days after housing) and by artificial inoculation (from the 5th to 35th days after the inoculation). The reason for these deifferences has not yet been clarified.

As shown in Table 3, the time required for each developing stage of the chicken mites parasitizing in the daytime were the same as those of the common chicken mites. These results agreed with those in the previous studies on the life cycle of common chicken mites (Wood, 1917 ; Wisseman \& Sulkin, 1947 : Sikes \& Chamberlain, 1954). No particular distinction was obseved in the life cycle of the chicken mites parasitizing in the daytime.

\section{References}

ARENDS, J.J. (1991) External parasites and poultry pest. In 'Diseases of poultry. 9th ed, (B.W. Calnek, H.J. Barns, C.W. Beard, W.M. Reid and H.W. Yorder Jr., eds.)' pp. 718-720. Iowa State University Press, Ames.

Baker, E.W., T.M. Evans, D.J. Gould, W.B. Hull and H.L. Keegan (1958) A Manual of parasitic mites of medical or economic importance. pp. 12-16. National Pest Control Association Inc. New York.

Devaney, J.A. (1979) The effects of the northern fowl mite, Ornithonyssus sylivarium on egg production and body weight of caged White Leghorn hens. Poultry Science, 58 : 191-194.

HaRRISON, I.R. (1963) Population studies on the poultry red mites Dermanyssus gallinae (DEG). Bulletin of Entomological Research, 53 : 657-664.

Kirkwood, A. (1963) Longevity of the mites Dermanyssus gallinae and Liponyssus sylviarum. Experimental Parasitology, $14: 358-366$.

NakAmae, H., S. Kishi, K. FuJisaki, S. Oshiro and K. Furuta (1996 a) Effect of trimming feathers off abdominal and crural tracts of the hen on parasitism of mites. Japanese Poultry Science, 33, 367-372.

Nakamae, H., K. Fujisaki, S. Kishi, M. Yashiro, S. Oshiro and K. Furuta, (1996b) The new parasitic ecolog y of chicken mites Dermanyssus gallinae parasitizing and propagating on chickens even in the day time. Japanese Poultry Science, $34: 110-116$.

Sikes, R.K. and Chamberlain, R.W. (1954) Laboratory observations on three species of bird mites. Journal of Parasitology, $40: 691-697$.

Wisseman, C.L. Jr. and Sulkin, S.E. (1947) Observations on the laboratory care, life cycle, and host of the chicken mite Dermanyssus gallinae. American Journal of Tropical Medicine, 27 : 463469.

Wood, H.P. (1917) The chicken mite : Its life history and habits. United States Department of Agriculture Bulletin No. 553, 1-14. 


\title{
鷄に常在寄生するワクモの寄生発生とワクモの生活環
}

\author{
中前 均 ${ }^{1} \cdot$ 岸 茂行 ${ }^{2} \cdot$ 藤崎幸蔵 $^{3} \cdot$ 大城政一 ${ }^{4} \cdot$ 古田賢治 $^{4}$ \\ ${ }^{1}$ 鹿児島大学大学院連合農学研究科, 鹿児島市郡元 890 \\ 2 愛知県西三河家畜保健衛生所, 岡崎市美合町地蔵野 444 \\ 3 農林水産省国際農林水産業研究センター, つくば市大わし 305 \\ ${ }^{4}$ 琉球大学農学部, 沖縄県西原町下佰 903-01
}

養鵎場に打いて常在寄生ワクモの寄生発生を観察し た. 次に常在寄生ワクモの卵を粰化して得た第一若ダニ を鶏に人工的に接種し，寄生の発生について観察した. さらに，常在寄生ワクモの生活環を調べた。

トリサシダニとワクモが寄生している鵎が飼育されて いる養鶏場のケージ鵎舎に，寄生を受けていない鶏を収 容すると，最初にトリサシダニの寄生がみられ，次にト リサシダニとワクモの共寄生状態となった。 やがてトリ サシダニの寄生はなくなり, ワクモの単独寄生の状態之 なった。これらのワクモは夜明けに鶏体から離脱するこ となく，屋夜を通じて䊿に寄生していた。

既にトリサシダニが寄生している鶏に常在寄生性のワ クモの第一若ダニを接種すると常在寄生が成立したが,
ワクモの奇生がない鶏に接種しても同様に奇生が成立し た。トリサシダニが寄生している鶏にワクモが寄生する と, 1 羽当たりの寄生ダ二数は 1,000-10,000の範囲に あったが，トリサシダニの寄生がない鶏では 100 以下で あった，鶏 1 羽に寄生するワクモ数が少ないため, 常在 寄生性ワクモの存在が見落とされていたと考えられる.

常在寄生性ワクモの生活環は夜間に鶏から吸血し夜明 けに鶏体から離脱する既知のワクモの生活環と同じで あった.

（家禽会誌, 34:240-247, 1997） キーワード: 寄生, ワクモ, トリサシダ二, 常在奇生性 ワクモ, 生活環 